\title{
MODEL PENGEMBANGAN PARIWISATA BAHARI BERBASIS MASYARAKAT DI KABUPATEN HALMAHERA UTARA
}

\author{
Aderius Sero \\ Dinas Kebudayaan dan Pariwisata \\ Kabupaten Halmahera Utara
}

\begin{abstract}
This research aimed to (1) study perception of people and private institution on maritime tourism development in Tagalaya, Kumo and Kakara in North Halmahera regency and (2) to study implementation of the community based maritime tourism development in Tagalaya, Kumo and Kakara in North Halmahera regency.

It used descriptive method to describe and analyze perception and participation and people empowerment activity. It used qualitative approach, which result in descriptive data in form of written or oral words of observed people. The processed data was then discussed systematically to get picture of the condition with final results of conclusion. Data was collected through in-depth interview, observation and documentation with informants of people, government, and administrator of tourism resorts selected purposively.

Results of the research indicated that first: people perceive the development model as providing work. They perceived tourism facility should be improved. About human resources, they perceive that it was very supporting. In addition they perceive management of the tourism object is low indicated with less optimal service level. Moreover, promotion was required with improvement of the resorts first. Second: people in the three tourism resorts participated in the maritime tourism development. The participation was in attending meeting, dissemination, security and order/cleanness. Their contribution was manifested in form as management of tourism object, establishing food shop, providing home stay, preparing maritime transportation, doing tourism infrastructure development project in the resorts and cooperating with private sectors. Community empowerment was done through development of tourism village by government of administrator through training and education, dissemination, partnership, and capital aid for infrastructure development.

Maritime tourism development model in North Halmahera regency can be implemented in human resource, management, and more intensive promotion, community participation and empowerment to create the integrated planning and management.
\end{abstract}

\section{Keywords:}

model, development, maritime tourism, community based.

\section{INTISARI}

Penelitian ini bertujuan untuk: 1). mengetahui persepsi masyarakat, pemerintah dan swasta terhadap model pengembangan pariwisata bahari di Pantai Tagalaya, Kumo dan 
Kakara Kabupaten Halmahera Utara; 2). Mengetahui model pengembangan pariwisata bahari berbasis masyarakat yang diterapkan di pantai Tagalaya, Kumo dan Kakara.

Peneliti menggunakan metode deskriptif untuk menggambarkan dan menganalisis persepsi, partisipasi dan kegiatan pemberdayaan masyarakat. Studi ini menggunakan pendekatan kualitatif, yang menghasilkan data deskriptif berupa kata tertulis atau lisan dari orang yang diamati. Data yang diolah kemudian dibahas secara sistematis untuk mendapatkan gambaran kondisi dengan hasil akhir sebagai penutup. Data dikumpulkan melalui wawancara mendalam, observasi dan dokumentasi dengan informan dari masyarakat, pemerintah, dan petugas objek wisata dipilih secara sengaja.

Hasil penelitian menunjukkan, bahwa: 1). model pembangunan fasilitas wisata menyediakan dapat lapangan kerja. Mereka menganggap fasilitas pariwisata harus ditingkatkan. Sumber daya manusia harus ditingkatkan, pengelolaan objek pariwisata yang rendah ditandai karena tingkat pelayanan yang kurang optimal. Selain itu, promosi yang diperlukan dengan peningkatan satu resor pertama. Kedua: orang di tiga resort pariwisata berpartisipasi dalam pengembangan wisata bahari. Partisipasi itu dalam menghadiri pertemuan, penyebaran, keamanan dan ketertiban / kebersihan. Kontribusi mereka diwujudkan dalam bentuk pengelolaan obyek wisata, mendirikan toko makanan, menyediakan home stay, mempersiapkan transportasi maritim, pariwisata melakukan proyek pembangunan infrastruktur di resort dan bekerja sama dengan sektor swasta. Pemberdayaan masyarakat dilakukan melalui pengembangan desa wisata oleh pemerintah administrator melalui pelatihan dan pendidikan, penyebaran informasi, kemitraan, dan bantuan modal untuk pembangunan infrastruktur.

Wisata Bahari pengembangan model di Halmahera Utara Kabupaten dapat diimplementasikan dalam sumber daya manusia, manajemen, dan promosi yang lebih intensif, partisipasi dan pemberdayaan masyarakat untuk menciptakan perencanaan terpadu dan manajemen.

\section{Kata Kunci:}

model, pembangunan, wisata bahari, berbasis masyarakat.

\section{LATAR BELAKANG}

Kabupaten Halmahera Utara memiliki potensi bahari yang sangat menjanjikan untuk dikembangkan menjadi daerah tujuan wisata karena karakter daerahnya adalah kepulauan, didukung dengan kawasan lautan yang terbentang luas serta memiliki berbagai potensi pariwisata baik alam dan budaya yang cukup beragam, memiliki wilayah pesisir dan lautan yang ekosisitemnya yang berkembang dengan baik dan terlindungi secara alamiah. Beberapa daya tarik wisata bahari yang terdapat di Kabupaten Halmahera Utara, antara lain: Pulau Tagalaya, Pantai Kakara, Pantai Kupa-Kupa, Pantai Kumo, Pantai Luari, Taman laut Tobotobo, dan Pulau Bobale.

Pembangunan pariwisata di Halmahera Utara lebih diarahkan pada spot-spot tertentu sesuai potensi yang ada. Spot-spot tersebut adalah: wisata budaya, wisata sejarah, wisata pesisir dan bahari, dan wisata alam lainnya. Permasalahan yang timbul adalah: fasilitas diobyek wisata kurang memadai, perawatan dan pengelolaan kurang optimal serta belum adanya keterlibatan masyarakat, swasta atau pelaku wisata secara baik. Selain itu dalam pengembangan pariwisata, pemilik obyek maupun pemerintah dihadapkan pada permasalahan: keterbatasan dana, sumberdaya manusia (khususnya dalam bidang pariwisata) serta masih adanya kepentingan lain (selain pariwisata) dimana Halmahera Utara yang baru dimekarkan menjadi kabupaten baru pada tahun 2003, sehingga pemerintah masih memfokuskan pada bidang-bidang lain yang dianggap penting (keamanan, perbaikan sarana dan prasarana umum).

Pembangunan pariwisata memberikan dua dampak yang mungkin terjadi kepada masyarakat setempat, yaitu pariwisata akan 
meningkatkan kesejahteraan bagi masyarakat atau justru sebaliknya, pariwisata akan memarginalkan masyarakat dari segala bidang. Hal tersebut sesuai dengan Harrison dalam Pitana (2005:122) yang menyatakan bahwa pariwisata membawa berbagai peluang baru bagi masyarakat. Sebaliknya, apabila masyarakat tidak mampu memanfaatkan peluang pariwisata, maka keberadaannya akan semakin marginal di tengah perkembangan pariwisata di daerahnya.

Paradigma pembangunan pariwisata dewasa ini berbeda dengan sebelummya dimana pembangunan pariwisata harus mengedepankan partisipasi dan pemberdayaan masyarakat guna peningkatan kesejahteraan, dikenal dengan pembangunan pariwisata berbasis masyarakat. Pitana (2005:109) menyatakan bahwa pariwisata adalah suatu kegiatan yang secara langsung menyentuh dan melibatkan masyarakat sehingga membawa berbagai dampak terhadap masyarakat setempat. Oleh karenanya, masyarakat di sekitar obyek wisata perlu mengetahui perkembangan pengembangan pariwisata di daerahnya dan segala unsurnya termasuk pelayanan (Suwantoro, 2004:23). Agar masyarakat mengetahui arti pentingnya pariwisata bagi masyarakat maka sosialisasi dan pendekatan dari pemerintah daerah mengenai pariwisata perlu dilakukan.

Sebagaimana Suwantoro (2004:29) mengemukakan bahwa sosialisasi wacana pariwisata bagi masyarakat sekitar lokasi obyek wisata sangat penting, sebab akan mendorong masyarakat untuk berperan serta membantu pengembangan pariwisata. Masyarakat akan tertarik untuk ikut menunjang pembangunan pariwisata apabila masyarakat telah memahami bahwa akan memperoleh manfaat yang positif. Jika masyarakat sudah beranggapan pariwisata akan bermanfaat baginya, maka dengan sendirinya akan berpartisipasi mengembangkan pariwisata di daerahnya yang sesuai dengan kondisi daerah dan kultur masyarakat setempat. Untuk menjamin supaya pariwisata dapat berkembang secara baik dan berkelanjutan, mendatangkan manfaat bagi masyarakat, serta meningkatkan peranserta masyarakat dan meminimalisasi dampak negatif yang mungkin timbul maka pengembangan pariwisata diupayakan melalui pendekatan model pengembangan pariwisata berbasis masyarakat.

\section{PERUMUSAN MASALAH}

Salah satu yang dikembangkan dalam pembangunan pariwisata di Kabupaten Halmahera Utara adalah pariwisata bahari. Dalam upaya pengembangan pariwisata bahari pemerintah daerah (cq. Disbudpar) sebagai pengembang aktif melakukan kegiatan pembangunan dan pembenahan obyek wisata, sosialisasi dan pembinaan kepada masyarakat setempat serta peran dari masyarakat, misalnya: menjaga lingkungan sekitar lokasi wisata, memanfaatkan peluang usaha yang muncul dan menjadi penggerak masyarakat sadar wisata di daerahnya. Oleh karena bagaimana masyarakat setempat menanggapi pengembangan pariwisata bahari di daerahnya serta bagaimana model pengembangan pariwisata bahari berbasis masyarakat yang diterapkan menarik untuk diketahui.

\section{TUJUAN DAN MANFAAT}

Adapun tujuan penelitian ini adalah: 1). Mengetahui persepsi masyarakat, pemerintah dan swasta terhadap model pengembangan pariwisata bahari di Pantai Tagalaya, Kumo dan Kakara Kabupaten Halmahera Utara.; 2). Mengetahui model pengembangan pariwisata bahari berbasis masyarakat yang diterapkan di pantai Tagalaya, Kumo dan Kakara.

Manfaat Penelitian adalah: 1). Sebagai bahan informasi bagi masyarakat dalam memahami berbagai persepsi masyarakat, pemerintah dan swasta terhadap model pengembangan pariwisata bahari, serta bagaimana pelaksanaan pengembangan pariwisata bahari berbasis masyarakat yang di lakukan oleh pemerintah daerah, 2). 
Sebagai bahan pertimbangan dalam menyusun peraturan dan kebijakan pembangunan pariwisata, dan sekaligus sebagai referensi untuk mengevaluasi pembangunan pariwisata bahari di Kabupaten Halmahera Utara.

\section{METODE PENELITIAN}

\section{Jenis Penelitian}

Jenis penelitian yang digunakan dalam adalah deskriptif. Whitney (1960) dalam Nasir (1988), bahwa penelitian deskriptif mempelajari masalah dalam masyarakat, tata cara yang berlaku serta situasi-situasi tertentu termasuk tentang hubungan, kegiatan, sikapsikap, pandangan-pandangan, serta prosesproses yang sedang berlangsung dan pengaruh dari suatu fenomena. Penelitian deskriftif yaitu penelitian yang berusaha mendeskripsikan menggambarkan fenomena atau hubungan antar fenomena yang diteliti dengan sistematis faktual dan akurat (Kusmayadi, 2000).

\section{Sumber Data dan Alat Penelitian}

Data yang dikumpulkan dibagi menjadi dua yaitu data primer dan data sekunder. Data Primer diperoleh melalui survey dengan melakukan pengamatan lapangan dan wawancara. Pengamatan lapangan dan wawancara dilakukan kepada pemerintah, swasta maupun masyarakat mengenai persepsi mereka terkait dengan pengembangan pariwisata bahari, serta model pelaksanaan pengembangan pariwisata bahari yang berlangsung di Halmahera Utara.

Data Sekunder diperoleh dengan cara menghimpun dan mengumpul an dokumen yang berhubungan dengan pengembangan pariwisata bahari, baik dalam bentuk rencana, laporan dari lembaga/instansi terkait, fotofoto/gambar dan hasil rekaman, buku-buku kepustakaan, majalah, tabloid, surat kabar, dan peraturan yang berlaku. Sumber data diperoleh dari: Dinas Pariwisata dan Kebudayaan, BAPPEDA, Dinas Tata Kota, Biro Pusat Statistik, Kantor Desa, Kantor Kecamatan rumah makan, penginapan dan biro trevel/jasa lainnya.

\section{Teknik Pengumpulan Data}

Untuk memperoleh data dan informasi yang diperlukan teknik pengumpulan data yang digunakan adalah: (1). Pengamatan (observation) terhadap pembangunan pariwisata bahari dan pengaruhnya bagi masyarakat, yaitu melihat sejauh mana persepsi, keterlibatan dan pemberdayaan masyarakat terhadap pengembangan pariwisata bahari yang ada di kawasan wisata; (2). Wawancara (inteview), dilakukan dengan wawancara mendalam (indepth interview), dimana peneliti datang ke masing-masing kelompok masyarakat. Selain wawancara langsung penulis juga meminta informan untuk menambahkan informasi lebih rinci secara tertulis, sehingga dapat dipakai sebagai bahan dokumentasi yang lengkap. Wawancara dilakukan secara mendalam dengan menunjuk informan yaitu pihak tokoh dan anggota masyarakat, pihak pemerintah, unsur swasta yang terkait dengan bidang pariwisata. Teknik yang digunakan adalah wawancara langsung dari subyek penelitian melalui tanya jawab sesuai dengan pokok permasalahan, bebas terpimpin dan dapat diperdalam dan dikembangkan sesuai dengan kondisi dilapangan.

Pokok-pokok wawancara adalah: a). Persepsi masyarakat terhadap pembangunan pariwisata bahari, diketahui dari hasil pengamatan dan wawancara, mengenai: peluang kerja dan lapangan kerja, fasilitas sarana, pengelolaan, pengembangan SDM, serta pemasaran/ promosi pariwisata; b). Pelaksanaan model pengembangan pariwisata bahari berbasis masyarakat untuk mengetahui bagaimana partisipasi dan pemberdayaan masyarakat dalam pengembangan wisata bahari, sumbangan tenaga, pikiran, memelihara dan mengembangkan daya tarik wisata, serta bagaimana pelatihan yang diterapkan dalam pengembangan sumberdaya masyarakat setempat. (3). Dokumentasi, Teknik dokumentasi dilakukan dengan melakukan penelusuran terhadap data-data tertulis yang memiliki relevansi dengan permasalahan yang diteliti.

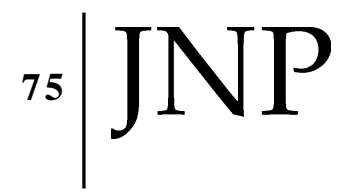


Data-data tertulis tersebut dapat berupa: laporan hasil penelitian terdahulu, dokumen resmi dan buku-buku yang sesuai dengan permasalahan yang dikaji. Foto juga dapat digunakan sebagai data tambahan, karena sifatnya merekam dan mendokumentasikan kehidupan sosial yang diteliti.

\section{Teknik Pemilihan Responden.}

Teknik pengambilan sampel dilakukan dengan lebih dahalu mendata semua responden yang terkait, kemudian diambil beberapa orang/unsur secara porposive sampling untuk dijadikan responden/sumber data, yang dianggap bisa mewakili dengan cara melakukan wawancara maupun dalam bentuk pertanyaan secara langsung. Informan yang berhasil dihimpun berjumlah 32 orang. Responden yang menjadi sumber informasi terdiri dari: (1). Masyarakat, Responden dari unsur masyarakat yang diwawancarai adalah masyarakat yang bermukim disekitar kawasan wisata yaitu tokoh masyarakat, pemuda, tokoh adat, pengelola, serta masyarakat yang terlibat dalam pengembangan kegiatan pariwisata dan menerima dampak dari pengembangan tersebut. (2). Pemerintah, Dari unsur pemerintah, hanya difokuskan dari istansi/ badan terkait yang terlibat dalam pengembangan pariwisata. Untuk unsur desa, hanya pada desa yang terdapat obyek wisata. Adapun dalam melakukan wawancara kepada pihak pemerintah (instansis/badan dan desa) bisa diwakilkan kepada orang-orang yang dianggap bisa mewakili. Diantara unsur pemerintah yang dipilih adalah: Dinas Pariwisata dan Kebudayaan, staf Kecamatan, Desa Kakara, Desa Kumo, dan Desa Tagalaya; (3). Swasta. Dari unsur swasta antara lain dengan menunjuk langsung pemilik/pelaku pariwisata: yaitu restoran, hotel/penginapan, biro perjalanan wisata/trevel.

\section{Analisis Data}

Penelitian deskriptif ini menggunakan analisis data secara induktif, yang artinya pengumpulan data bukan dimaksudkan untuk membuktikan hipotesis akan tetapi lebih merupakan pembentukan abstraksi berdasarkan bagian-bagian yang telah dikumpulkan. Dalam hal ini analisis data dilakukan dengan memahami dan merangkai data-data yang telah dikumpulkan secara sistematis. Analisis yang dilakukan adalah untuk membuktikan respon masyarakat terhadap persepsi masyarakat, bagaimana partisipasi dan pemberdayaan masyarakat dengan melihat pada alasan dari tanggapan tadi. Dari data sekunder yang dimiliki dan didukung oleh data primer atau hasil wawancara, kemudian dilakukan identifikasi dan pengelompokan dari setiap responden. Dengan demikian diperoleh kesimpulan dalam menjawab permasalahan penelitian.

\section{HASIL DAN PEMBAHASAN \\ 1. Persepsi Masyarakat terhadap Pengembangan Pariwisata Bahari Berbasis Masyarakat}

Pada umumnya masyarakat akan menilai positif setiap kebijakan yang diterapkan apabila kebijakan tersebut berpihak kepada masyarakat serta dapat memecahkan persoalan yang mereka hadapi. Sebaliknya masyarakat akan memberikan penilaian yang negatif bila kebijakan tersebut merugikan mereka atau menghambat akses mereka kepada sumber-sumber mata pencaharian. Persepsi terhadap peluang usaha/ peluang kerja, pengembangan sumberdaya manusia, prasarana pariwisata, pengelolaan dan promosi dijelaskan sebagai berikut:

a. Peluang Usaha atau Lapangan Kerja Menurut Fandeli (2005), pengaruh kegiatan pariwisata mendorong tumbuhnya industri kecil, perdagangan, dan munculnya pusat pertumbuhan yang tersebar hingga ke pedalaman. Dari aspek ekonomi, dampak pariwisata menjanjikan untuk pemberdayaan masyarakat dan penciptaan lapangan kerja, seperti penyediaan jasa, kebutuhan akomodasi dan logistik sehingga dapat meningkatkan pendapatan masyarakat lokal. Hasil penelitian 
menunjukkan bahwa tanggapan masyarakat untuk ketiga obyek wisata tersebut sangat positif, mereka menyambut baik pengembangan pariwisata yang ada, walaupun mereka menyadari bahwa pasti juga akan menimbulkan dampak negatif. Masyarakat yang setuju dengan pegembangan pariwisata karena telah memberikan manfaat bagi mereka dimana telah meningkatkan pendapatan masyarakat, menambah lapangan kerja baru seperti usaha transportasi laut, membuka penginapan/homestay, warung makanminum meningkatkan kerajinan tangan yang dijual. Selain alasan ekonomi, adapula masyarakat yang mengharapkan dengan ramainya kunjungan wisatawan akan membuka kontak dengan budaya luar.

Berdasarkan hasil wawancara dan pengamatan lapangan diketahui pula bahwa adanya kesadaran masyarakat merespon positif pengembangan obyek wisata dengan memanfaatkan peluang yang ada. Masyarakat dengan inisiatif sendiri, berkoordinasi dengan pengelola dan pihak pemerintah membangun warung makan dalam kawasan pantai obyek wisata, menyediakan sarana angkutan laut dengan modal sendiri.

Alat transportasi di obyek wisata, sejumlah 24 unit perahu ketinting semuanya adalah milik masyarakat. Semulanya hanya ada 7 unit ketingting yang menghubungkan masyarakat dengan kota. Namun seiring dengan adanya pengembangan obyek wisata, maka masyarakat menggunakan kesempatan untuk berusaha di bidang transportasi laut.

Selain itu, mengingat belum ada hotel/penginapan di kawasan, maka masyarakat mencoba mengatasinya dengan membuka usaha penginapan (homestay) dengan memanfaatkan sebagian rumahnya. Tarif per kamar/per hari berkisar antara Rp.30.000,- hingga
Rp.50.000,- dengan fasilitas kamar dan 1 buah tempat tidur kasur ukuran double dan kamar mandi luar (digunakan bersama).

Hasil penelitian juga menunjukan bahwa masyarakat yang terlibat dalam aktivitas wisata bahari terutama berjualan makanan dan minuman, jasa transportasi laut ke dan dari obyek wisata memperoleh pendapatan yang cukup tinggi. Bagi pelaku jasa transportasi laut berkisar Rp. 200.000,- s/d Rp. 300.000,- setiap hari. Bagi warung makan-minum memperoleh pendapatan Rp. 500.000,- s/d Rp. 1.200.000,- per hari libur (minggu).

Berikut beberapa gambaran peluang usaha akibat adanya pengembangan wisata bahari.

Tabel 1.

Peluang Usaha yang Tercipta bagi Masyarakat Lokal

\begin{tabular}{|c|c|c|c|}
\hline No. & $\begin{array}{c}\text { Peluang Usaha Yang } \\
\text { Tercipta Bagi } \\
\text { Masyarakat Lokal }\end{array}$ & Pelaku Usaha & Keterangan \\
\hline 1 & $\begin{array}{l}\text { Penyediaan Fasilitas } \\
\text { Penginapan (Hotel, } \\
\text { Penginapan, } \\
\text { Homestay) }\end{array}$ & $\begin{array}{c}\text { Masyarakat } \\
\text { lokal, }\end{array}$ & $\begin{array}{l}\text { Hotel, Penginapan, } \\
\text { homestay dikelola } \\
\text { oleh masyarakat } \\
\text { lokal. }\end{array}$ \\
\hline 2 & $\begin{array}{l}\text { Penyediaan Fasilitas } \\
\text { Rumah Makan, } \\
\text { Restoran }\end{array}$ & $\begin{array}{c}\text { Masyarakat } \\
\text { lokal }\end{array}$ & $\begin{array}{l}\text { rumah makan } \\
\text { dikelola oleh } \\
\text { masyarakat lokal }\end{array}$ \\
\hline 3 & Pedagang Souvenir & $\begin{array}{c}\text { Masyarakat } \\
\text { Lokal }\end{array}$ & $\begin{array}{l}\text { Hanya sebagai } \\
\text { profesi sampingan }\end{array}$ \\
\hline 4 & Warung, Kios & $\begin{array}{c}\text { Masyarakat } \\
\text { lokal }\end{array}$ & $\begin{array}{l}\text { Sebagai profesi } \\
\text { utama, (melayani } \\
\text { wisatawan dan } \\
\text { kebutuhan sehari- } \\
\text { hari). }\end{array}$ \\
\hline 5 & Transportasi laut & $\begin{array}{c}\text { Masyarakat } \\
\text { lokal, } \\
\text { Pengusaha }\end{array}$ & $\begin{array}{l}\text { Sebagai profesi } \\
\text { utama, (melayani } \\
\text { wisatawan dan } \\
\text { kebutuhan sehari- } \\
\text { hari). }\end{array}$ \\
\hline 6 & Pedagang Asongan & $\begin{array}{c}\text { Masyarakat } \\
\text { lokal }\end{array}$ & $\begin{array}{l}\text { Hanya sebagai } \\
\text { profesi sampingan }\end{array}$ \\
\hline 7 & $\begin{array}{l}\text { Pengelola obyek } \\
\text { wisata }\end{array}$ & $\begin{array}{c}\text { Masyarakat } \\
\text { lokal }\end{array}$ & $\begin{array}{l}\text { Sebagai pengelola } \\
\text { obyek }\end{array}$ \\
\hline
\end{tabular}

b. Sumberdaya Manusia (SDM)

Hasil penelitian menunjukan masyarakat sangat mendukung adanya kegiatan pengembangan SDM, hendaknya ada kerjasama dengan pihak-pihak terkait, terutama para pelaku pariwisata. Mengingat SDM yang ada di Halmahera Utara, baik 
masyarakat di sekitar obyek wisata maupun di Dinas Pariwisata dan Kebudayaan masih sangat minim, maka perlu ada upaya peningkatan.

Pengembangan SDM melalui pelatihan atau kursus bisa menambah pengetahuan dan ketrampilan masyarakat untuk bisa berperan aktif sebagai pengembang obyek wisata. Dengan pengembangan SDM diharapkan dapat merubah cara pikir masyarakat, dari yang kurang peduli menjadi peduli. Masyarakat merupakan salah satu komponen penting dalam pengembangan pariwisata harus mempunyai kualitas, agar mampu berperan aktif dalam pengembangan pariwisata bahari.

c. Sarana Prasarana Wisata

Sarana dan prasarana yang diharapkan tersedia di sekitar obyek wisata adalah pusat informasi, tempat penginapan, restoran atau warung makan, toko cenderamata sarana komunikasi, air bersih, listrik, WC/ kamar mandi, tambatan perahu, alatalat diving, snorkling, dan yang lainnya. Ketiga obyek wisata tersebut saat ini belum memiliki sarana prasarana tersebut, karenanya perlu ada usaha pengadaan.

Hasil pengamatan terhadap bentuk akomodasi dan pangadaan fasilitas yang menjadi prioritas utama, adalah: 1) sarana air bersih, wc/ kamar mandi, listrik; 2) tempat duduk istirahat/santai, warung makan;3) perlengkapan renang, tambatan perahu (pelabuhan wisata).

Berdasarkan pengamatan lapangan serta wawancara dengan masyarakat menunjukan bahwa masyarakat mendukung dan merasa perlu adanya pengembangan terhadap ketersediaan fasilitas pariwisata, karena masih terdapat kekurangan fasilitas yang tersedia di kawasan obyek wisata sehingga perlu adanya penambahan akomodasi dan fasilitas tiga obyek wisata tersebut. Perlu adanya koordinasi dan kerjasama antara pihak-pihak yang terkait dalam pengadaan sarana prasarana pariwisata di ketiga obyek wisata tersebut. Selain itu perlu dilaksanakan pengawasan dan pengontrolan, baik berupa perawatan pemeliharaan sehingga bisa tetap terawat dengan baik.

\section{d Pengelolaan Obyek Wisata}

Persepsi masyarakat terhadap pengelolaan obyek wisata secara umum kurang baik. Dari hasil lapangan dan wawancara, menunjuk kan bahwa pengelolaan terkesan kurang baik, air bersih masih kurang, sarana dan prasarana terbatas, tidak terawat, kebersihan lingkungan masih perlu dibenahi, sampah tidak belum terurus, perlu penataan pedagang kecil.

Hasil penelitian menunjukan bahwa pengelolaan obyek belum optimal. Terlihat dari masih terbatasnya pelayanan, disebabkan karena faslitas yang masih kurang, penataan fasilitas wisata tidak sesuai dengan peruntukan, penanganan sampah kurang baik dan kurang tersedianya tempat sampah sehingga banyak sampah yang berhamburan di lokasi obyek wisata.

\section{e. Pemasaran atau Promosi}

Hasil pengamatan dan wawancara menunjukkan bahwa selama ini pemerintah telah berupaya melakukan promosi melalui internet, brosur, leaflet, bahkan mengikuti kegiatan pameran sampai ke luar daerah, bahkan sampai ke negeri Belanda. Namun tentunya belum menunjukkan hasil yang maksimal.

Persepsi masyarakat terkait dengan pemasaran dan promosi berdasarkan hasil wawancara diketahui bahwa, masyarakat sangat mendukung dan menyambut baik kegiatan pemasaran dan promosi pariwisata yang dilakukan 
oleh pemerintah daerah maupun pengelola, namun yang perlu dilakukan sebelumnya adalah penataan obyek atau kawasan supaya layak untuk dijual dan promosikan.

\section{Model Pengembangan Pariwisata Bahari Berbasis Masyarakat di Pantai Tagalaya, Pantai Kumo dan Pantai Kakara}

Model pengembangan pariwiata berbasis masyarakat merupakan suatu bentuk/pola pembangunan pariwisata yang mengedepankan pembangunan dengan mengupayakan peran serta masyarakat untuk ambil bagian dalam setiap proses perencanaan, pelaksanan dan evaluasi pelaksanaan, agar masyarakat tidak lagi sebagai obyek tetapi selaku pelaksana pembangunan demi kesejahteraan mereka sendiri.

\section{i. Bentuk Partisipasi dan Peran serta Masyarakat}

Berkaitan dengan model pengembangan pariwisata bahari berbasis masyarakat di pantai Tagalaya, Kumo dan Kakara, menurut hasil observasi dan wawancara dengan tokoh masyarakat, pemuda, dan pengelola serta pemerintah, dan beberapa orang dari masyarakat yang dilibatkan dalam penelitian, menunjukkan bahwa partisipasi masyarakat dalam kegiatan pengembangan pariwisata di ketiga obyek wisata tersebut dibedakan dalam 2 (dua) kategori, partisipasi langsung dan partisipasi tidak langsung.

\section{Partisipasi Tidak Langsung}

Hasil penelitian menunjukkan, peranserta masyarakat seacara tidak langsung adalah dengan memberikan pendapat, tanggapan/keberatan, atau masuk-an serta pemberian data atau informasi yang dapat dipertanggung jawabkan. Misalnya pada saat presentasi penyusunan RIPPDA dan RIPOW beberapa anggota masyarakat diundang untuk memberikan sumbangan pikiran dan pendapat, gagasan-gagasan.
Bentuk peranserta tidak langsung lainnya adalah masyarakat selalu dilibatkan dalam kegiatan penyuluhan, pembinan, pelatihan untuk menambah pengetahuan, pemahaman tentang arti pentingnya pariwisata yang memberi manfaat langsung bagi kesejahteraan masyarakat. Demikian juga masyarakat bersama-sama pengelola obyek wisata ikut menjaga keamanan dan ketertiban lingkungan, kebersihan, menjaga tindakan perusakan terumbu karang, tindakan menagkap ikan disekitar area kawasan wisata dengan menggunakan bom ikan, potasium, pukat harimau, perusakan hutan mangrove. Masyarakat ikut menjaga, mencegah, dan melaporkan kepada pihak kepolisian apabila mengetahui terkait dengan pemboman ikan disekitar kawasan wisata. Masyarakat juga ikut melakukan pencegahan serta tidak lagi mengambil/ merusak karang-karang yang berada di lokasi wisata. Di obyek wisata Tagalaya dan Kakara masyarakat juga ikut menjaga dari tindakan masyarakat luar untuk tidak lagi mengambil, menebang hutan mangrov untuk keperluan rumah atau kayu bakar, karena akan merusak ekosistem dan mengurangi estetika kawasan obyek wisata, sehingga keberlanjutan obyek wisata terjaga dengan baik.

\section{Partisipasi Langsung}

Berdasarkan wawancara dan hasil pengamatan menunjukan ada peran serta langung dari masyarakat untuk ikut ambil bagian dalam pengembangan pariwisata bahari di obyek wisata. Beberapa keterlibatan/partisipasi langsung adalah: (a). Sebagai pengelola obyek wisata. Untuk mengoptimal kan dan mengkoordinasikan potensi sumber daya masyarakat yang terdapat di ketiga obyek wisata tersebut, pemerintah daerah membentuk tim pengelola obyek wisata. Tim pengelola 
obyek wisata berjumlah $17-18$ orang, terdiri dari dari unsur masyarakat sendiri. Tim ini berfungsi untuk mengelola dan mengembangkan obyek wisata masing-masing. Dengan tugas antara lain: menjaga kebersihan dan keindahan obyek wisata, menjaga dan merawat berbagai aset/inventaris obyek wisata, menjaga ketentraman dan kenyamanan obyek wisata, menjalankan karcis masuk dan pertanggungjawabannya. (b). Menjaga keamanan dan kebersihan kawasan wisata. Hasil penelitian menunjukan masyarakat berpartisipasi langsung dalam menjaga kebersihan lingkungan kawasan wisata. Hal ini merupakan tugas dan tanggung jawab bersama baik dari pemerintah, masyarakat sekitarnya, dan pengelola pariwisata itu sendiri. Setiap hari sabtu pengelola, pemuda, warga masyarakat bersama-sama membersihkan lokasi obyek wisata secara gotong-royong. (c). Pelaksanaan proyek pembangunan sarana wisata. Dalam pelaksanaan program yang menyangkut pembangunan fasilitas di obyek wisata, seperti: gazebo, rumah payung, pembangunan $\mathrm{WC} /$ kamar mandi, diving center, masyarakat selalu dilibatkan. Pembangunan sarana prasarana dibiayai oleh pemerintah dalam bentuk proyek, pelaksanaannya oleh pihak kontraktor, tetapi masyarakat yang mengerjakan dengan sistem gotong-royong dan diberi upah harian. (d). Menyediakan fasilitas warung makan, akomodasi transportasi, homestay. Dengan dilandasi kesadaran masyarakat, ikut berperan serta dalam menyediakan atau membangun warung makan, menyediakan transportasi laut, homestay. Ini menunjukkan pentingnya pariwisata bagi mereka. (e). Kerjasama dengan pihak swasta. Keberhasilan suatu obyek wisata tidak mungkin tercapai dengan baik apabila tanpa melibatkan komponen masyarakat lain atau sektor swasta. Pengem- bangan pariwisata di Halmaharea Utara, terutama obyek wisata yang ada merupakan langkah maju dengan menggalang semua pihak pelaku pariwisata untuk terlibat dalam pengembangan pariwisata. Ini harus disikapi dengan baik demi kesejahteraan masyarakat.

Sesuai hasil wawancara dengan pihak swasta khususnya pihak perhotelan/ penginapan maupun travel selama ini selalu dilibatkan dalam pengembangan kegiatan pariwisata. Dari hasil penelitian menunjukan bahwa adanya partisipasi atau peran serta aktif masyarakat dalam upaya pengembangan pariwisata bahari di ketiga oyek wisata pantai Tagalaya, Kumo dan Kakara Kabupaten Halmahera Utara karena merasa memiliki dan memperoleh manfaat dari obyek wisata tersebut.

\section{ii. Pemberdayaan Masyarakat}

Hasil penelitian mununjukkan kegiatan pemberdayaan yang dilakukan oleh pemerintah dan pengelola masih sebatas sosialisasi sadar wisata tentang "sapta pesona", sosialisasi pengamanan obyek wisata, pembinaan kepada masyarakat yang berusaha dalam bidang usaha jasa pariwisata, pelatihanpelatihan berupa pelatihan scuba diving, pelayanan para tamu hotel dan rumah makan, serta bantuan pembangunan sarana fisik pariwisata dilokasi obyek wisata. Bentuk kegiatan pemberdayaan masyarakat yang dilakukan oleh pihak pemerintah daerah dan pengelola adalah sebagai berikut:

\section{iii. Pelatihan-Pelatihan}

Hasil penelitian di ketiga obyek wisata bahari pantai Tagalaya, Kumo dan Kakara menunjukan bahwa salah satu upaya pemberdayaan masyarakat dalam usaha meningkatkan kemampuan untuk pariwisata bahari adalah dengan memberikan pelatihan pada masyarakat, antara lain: kerja sama dengan Thalasa Dive Center Manado di Sulawesi Utara, dimana untuk tahap pertama peme- 
rintah telah mengirim 26 anggota masyarakat sekitar obyek wisata untuk mengikuti kegiatan pelatihan diving tingkat pertama dan ke dua di Manado. Materi diving adalah Open Water, Deep Dive (AVD), EFR dan Rescue disertai prakternya di Taman Nasional Bunaken.

Tujuan dari kegiatan ini adalah melatih para diving guide yang nantinya diharapkan dapat memandu para wisatawan untuk menikmati kekayaan panorama alam bawah laut. Selain pelatihan diving, juga dilaksanakan pelatihan bagi karyawan hotel/ restoran. Pelatihan dilakukan dengan maksud membekali para karyawan agar dapat memberikan pelayanan yang lebih baik kepada konsumen atau tamu.

\section{iv. Pertemuan/Penyuluhan}

Penyuluhan atau kampanye sadar wisata dilakukan oleh pemerintah dan instansi terkait lainnya yang bertujuan untuk memberikan pengetahuan, penyadaran, dan bimbingan kepada masyarakat mengenai potensi-potensi yang dimiliki serta bagaimana cara mengembangkan sekaligus mengelola potensi tersebut menjadi atraksi wisata yang bermanfaat bagi kesejahteraan mereka. Dalam pertemuan atau penyuluhan ini masyarakat diberikan pemahaman atau pengarahan mengenai sapta pesona, menjaga keamanan dan ketertiban (pengamanan obyek wisaa, bagaimana membangun dan mengelola homestay dengan baik, (seperti tata cara menata ruangan, melayani tamu), dan menjaga kebersihan (MCK, dan lingkungan sekitar), bagaimana mengembangkan seni budaya untuk dijadikan aktrasi wisata.

\section{v. Pendampingan/Kemitraan}

Salah satu bentuk pendampingan/ kemitraan yang telah terjalin adalah mengadakan kerjasama dengan Thalassa Diving Center Manado. Kerjasama tersebut dimaksudkan agar pengelolaan obyek wisata bahari oleh masyarakat bisa berkembang dengan baik. Bentuk kerja yang sudah dilakukan adalah pendataan dan peliputan potensi bawah laut, kerja sama dengan
Thalassa Diving Center Manado dibantu oleh MacDonald Enterprise, Team Ekpedisi Metro, Kompas dan PT Mimpi Dive Cruises. Kegiatan pendataan tersebut dan peliputan berhasil mengidentifikasikan 40 titik selam (dive spot) baru dengan kondisi terumbu karang yang masih sangat baik. Selain terumbu karangnya dinilai layak jual, umumnya titik-titik selam ini juga menawarkan beragam biota laut seperti ikan hiu sirip putih, ikan hiu sirip hitam, lobster, udang, nudi branchs, barracuda, ikan scorpio, hiu leopard, ikan pipa hantu, dan beragam jenis ikan lainnya. Selain itu kerjasama dilakukan dengan PT. Gahawisri di Jakarta, Universitas Politeknik Padamara Halmahera Utara, konsentrasi Ekowisata, serta PKK Halmahera Utara yang melakukan pendampingan untuk kaum perempuan.

\section{vi. Bantuan Modal Pembangunan Sarana dan Prasarana Pariwisata}

Upaya pemberdayaan masyarakat dalam pengembangan pariwisata di ketiga obyek wisata, pihak pemerintah juga memberikan bantuan dana untuk membangun sarana dan prasarana wisata guna mendukung lancarnya kegiatan wisata. Bantuan proyek pembangunan sarana-prasaran wisata berupa membuat MCK/ kamar ganti, pembuatan saluran air bersih/sumur, bantuan modal usaha rumah makan. Kegiatan tersebut tidak semata-mata dikerjakan oleh pihak pengelola sebagai pelaku pemberdayaan, tetapi juga masyarakat terlibat secara aktif dan bekerja bersama. Hal ini dilakukan supaya tercipta rasa tanggung jawab (sense of responsible) dan rasa memiliki (sense of belonging) atas pembangunan yang telah dilakukan.

\section{KESIMPULAN DAN SARAN}

\section{Kesimpulan}

Beberapa kesimpulan yang dapat diperoleh dari pembahasan terdahulu adalah:

(1).Berkaitan dengan persepsi masyarakat terhadap pengembangan pariwisata bahari berbasis masyarakat: a). Peluang kerja dan lapangan kerja. Masyarakat mendukung pengembangan obyek

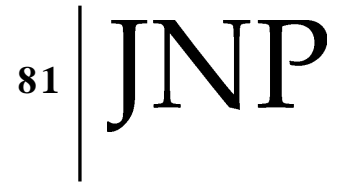


wisata karena mendatangkan peluang kerja dan lapangan kerja, seperti sebagai pengelola obyek, masyarakat membuka warung makan dan minum, menyiapkan rumah sebagai homestay, menyediakan sarana transpor-tasi laut, pedagang asongan; b). Masyarakat sangat mendukung program pengembangan SDM kearaha yang lebih berkualitas. c). Sarana wisata, fasilitas dan sarana wisata yang ada masih sangat kurang, masyarakat mendukung pengembangan sarana wisata. Perlu penambahan jaringan air bersih, jaringan listrik, fasilitas akomodasi, dan pemelihataan kebersihan lingkungan; d). Kualitas pengelolaan obyek wisata masih rendah, disebabkan oleh kualitas sumber daya manusia masih sangat terbatas; e). Promosi sangat dibutuhkan untuk kemajuan pariwisata, tetapu diperlukan pembenahan kawasan sebelum melakukan promosi.

(2). Partisipasi dan Peranserta Masyarakat dalam pengembangan pariwisata bahari berbasis masyarakat di ketiga obyek wisata sangat tinggi, terlihat dari tingkat partisipasi masyarakat baik langsung maupun tidak langsung. Partisipasi langsung yaitu antusias mengikuti berbagai pertemuan, pembinaan dan penyuluhan, menjaga keamanan dan ketertiban, mencegah kegiatan penangkapan ikan dengan bom ikan, potasium, pukat harimau, perusakan terumbuh karang dan penebangan hutan mangrove disekitar kawasan wisata. Sedangkan peranserta langsung yaitu sebagai pengelola obyek wisata, mendirikan warung makan, menyiapkan sarana transportasi laut, melaksanakan proyek pembangunan sarana wisata di obyek wisata.

(3). Pemberdayaan Masyarakat Adanya upaya pemberdayaan masyarakat yang dilakukan oleh pihak pemerintah dan pengelola terhadap masyarakat sekitar dalam bentuk pelatihan, pendidikanan, penyuluhan, pendampingan, bantuan modal pembangunan sarana dan prasarana. Implementasi bentuk kegiatan pemberdayaan tersebut disesuaikan dengan kebutuhan masyarakat.

\section{Saran}

a).Sosialisasi atau penyuluhan kepada masyarakat perlu terus dilakukan secara intensif agar masyarakat siap untuk dapat berperan dalam aktifitas pariwisata, menjadi masyarakat sadar wisata;

b). Mengikut sertakan masyarakat secara terusmenerus dalam workshop, pelatihan pengelolaan dan pengembangan obyek wisata;

c). Perlu adanya manajemen pengelolaan yang optimal, peningkatan sumberdaya manusia. Pihak pengelola diharapkan dapat bekerjasama dengan pihak-pihak terkait dalam penyelenggaraan kegiatan pemberdayaan masyarakat;

d). Untuk pemerintah daerah, kebijakan pembangunan pariwisata bahari lebih diprioritas pada peningkatan dan pembenahan infrastruktur/fasilitas sarana-prasarana pariwisata bahari, pengelolaan serta upaya promosi.

\section{DAFTAR PUSTAKA}

2007, Data Kepariwisataan Kabupaten

Halmahera Utara. (tidak dipublikasikan)

2007, Rencana Induk Pengembangan

Pariwisata Daerah, bekerja Sama

Dengan Pusat Studi Pariwisata UGM Yogyakarta.

Fandeli, C. 1995. Dasar-Dasar Kepariwisataan Alam, Liberty, Yogyakarta.

Fandeli, Chafid dan Mukhlison, ed., 2000. Pengusahaan Ekowisata. Yogyakarta, 
Fakultas Kehutanan Universitas Gadjah Mada.

Hutomo, Mardi Yatmo., 2000. Pemberdayaan Masyarakat dalam Bidang Ekonomi: Tinjauan Teoritis dan Implementasi. Makalah Seminar Sehari "Pemberdayaan Masyarakat" Bappenas, 6 Maret 2000 di Jakarta.

Moleong, L.J., 2002. Metodologi Penelitian Kualitatif. Bandung: PT. Remaja Rosdakarya.

Nasir, M. 1988. Metode penelitian. Jakarta: Ghalia Indonesia.
Myra Gunawan, Masyarakat Kurang Dilibatkan. Pengembangan Bisnis Wisata, Bisnis Indonesia, 10/05/01

Pitana, I.G. dan Putu G. Gayatri. 2005. Sosiologi Pariwisata, Penerbit Andi. Yogyakarta.

Sumarwoto, O. 2001. Ekologi Lingkungan Hidup dan Pembangunan, Penerbit Djambatan, Jakarta.

Suwantoro, G. 2004. Dasar-Dasar Pariwisata. Penerbit, Andi Yogyakarta. 